\title{
CONGOLESE ELECTIONS 2011 \\ Mostly a Problem of Global Governance and \\ Negative 'Soft Power', not Resources
}

\author{
Timothy B Reid
}

\begin{abstract}
Timothy B Reid has been involved in peacekeeping for more than 15 years, both in the military (Bosnia, Ethiopia-Eritrea) and as a civilian (Rwanda, Cambodia, the Democratic Republic of Congo, Lebanon and Libya). He has served as a justice and investigations officer for the UN Human Rights Field Operation in Rwanda, as a political affairs officer dealing with armed groups and a team leader for disarmament, demobilisation, repatriation, resettlement and reintegration in Bukavu, responsible for the South Kivu Province of the Congo. He holds an MPA from the John F Kennedy School of Government, Harvard University; an LLB from the University of Montréal; an MSc in international economy and a BAA from the École des hautes études commerciales Montréal. The opinions expressed in this article are the author's own and do not purport to represent those of the United Nations or any other organisation.
\end{abstract}

e-mail:timothyreid@hotmail.com

\begin{abstract}
When Congolese President Joseph Kabila was inaugurated for a second term on 20 December 2011 the fallout from the 28 November elections in the Democratic Republic of the Congo (DRC) was 'situation normal: continued instability'. After Kabila's main opponent, Etienne Tshisekedi, 'swore himself in' on 23 December (Tshisekedi website), there were two men claiming to be president and several other candidates demanding a new ballot. The 2006 elections, the DRC's first since the Global and Inclusive Agreement (Dialogue Inter-Congolais 2002), were shambolic, but clearly legitimate (UN 2007, Carter Center 2006a, b, c). This was partly due to the fact that the United Nations Organization Mission in the Democratic Republic of the Congo (Monuc) had a stronger presence than its successor, the United Nations Organization Stabilization Mission in the Democratic Republic of the Congo (Monusco). There was also more international attention in 2006, including an EU rapid reaction force. However, many of the issues in the 2011 election - violence, logistical problems and irregularities - were present in the previous one (see, eg, UN 2006; Carter Center 2006a, b, c). There was possibly as much international financial and logistical support
\end{abstract}


as there had been in 2006. There were fewer international observers but more local ones. The main differences relate to context, the structure of international assistance and the lack of a second presidential round. The crisis had been years in the making. More important than diminished engagement in the mechanics of the election was the international community's sham attention to governance in sub-Saharan Africa and the culture of impunity it has encouraged. The West, unlike China, has failed to appreciate the strategic importance of the DRC. By encouraging regional dictators instead of enthusiastically supporting the rule of law early and often, it tacitly encouraged bad behaviour.

\section{VOTERS AND OBSERVATION}

This article begins with a comparison of voter participation and electoral observation in 2011 with that in 2006. The statistics are somewhat ambiguous: though, in absolute terms, more people voted in 2011, the rate of participation decreased and the number of discarded ballots increased. These factors can be interpreted in different ways, relating to the quality of registration and voting in both years, but would not seem to be strong enough to enable a definitive judgement to be made. International observation was significantly down but domestic observation was considerably increased, proving that the DRC has a healthy civil society. The election, therefore, did not suffer from a 'lack of eyes on the target', though the diminished number of international observers probably represented diminished international attention, which plays an important role in the DRC's current situation.

In 2006, 25420199 people were entitled to vote. A total of 25712552 voters was registered but 292353 were excluded from the voters' roll for multiple registration (Nanitelamio 2008). The official turnout was 70.5\% (approximately 17921240 ) in the first round and 64.5\% (16396 028) in the second, run-off, round. There were $4.9 \%$ invalid and $0.7 \%$ blank ballots in the first round and $1.7 \%$ invalid and $0.4 \%$ blank ballots in the second (Carter Center 2006c). According to the Independent National Electoral Commission (La Commission Électorale Nationale Indépendante - CENI), in 2011 there were 32024640 voters, of whom 18911572 (59.05\%) voted, minus 768468 spoiled or blank ballots (4.1\%) for a final tally of $18143104(56.7 \%)$ 'valid voters'.

Putting aside potential manipulation, these figures show important slippage in the level of participation and an official doubling of discarded ballots (perhaps partly due to less funding from international donors for voter education (Carter Center 2011a). On the other hand, more people actually put ballots into boxes, perhaps saying something about the registration process. 
In 2006 the first round was observed by some 47500 national observers, 466000 political party witnesses and 1773 international observers (UN 2006). The 2011 presidential and legislative elections were observed by 108238 national observers, 1777130 political party witnesses, 785 international observers, 1747 Congolese journalists and 62 international reporters (CENI 2012a). The European Union Electoral Observation mission (EU EOM) consisted of 147 people drawn from the EU's 27 member states, including Norway, Switzerland, and Canada and comprising a core team of 10 experts, 46 long-term observers, 72 short-term observers and about 20 DRC-based diplomats on election day (EU 2012).

The Francophonie sent 16 (see Organisation Internationale de la Francophonie 2011). Several African regional associations also sent observer teams. The Southern African Development Community (SADC) sent about 200 (SADC 2011), which included DRC-based diplomats, and the Common Market for Eastern and Southern Africa (Comesa) sent 25. (The Times of Zambia 24 November 2011). There were also missions from the African Union (AU), the Economic Community of Central African States (ECCAS or Communauté Économique des États de l'Afrique Centrale - CEEAC) and the International Conference On The Great Lakes Region (ICGLR); however these appear to have been very small (numbers are not mentioned in their press releases and they did not respond to requests for information). The Carter Center sent 70 international observers, including 10 long-term observers from 17 August and another 10 after September.

There were significantly larger numbers of domestic observers than there had been in the previous election, despite a decline in international support for such groups (Carter Center 2011a). The Carter Center itself trained 300 longterm and 6000 short-term observers, deployed in all provinces. The Catholic Church deployed 30 000. The National Electoral Observation Mission ('Mission Nationale pour l'Observation électorale'), composed of four different Congolese organisations and supported by international NGOs, placed 12350 observers throughout the country. ${ }^{1}$ Some of its members sent out additional observers. The 'Observation Network of Religious Confessions' ('Réseau d'Observation des Confessions religieuses') deployed an additional 17 000. The joint mission of the European Network for Central Africa (Réseau Européen pour l'Afrique Centrale-EurAc) and AETA ('Agir pour les Élections Transparentes et Apaisées': Action for Transparent and Calm Elections) consisted of 12000 observers (AETA

1 The 'Mission Nationale pour l'Observation électorale' comprises the following Congolese organisations: Le Réseau National pour l'Observation et la Surveillance des Élections au Congo; Le Réseau d'Observation des Confessions religieuses; Le Cadre Permanent de Concertation de la Femme congolaise and Le Conseil National de la Jeunesse. They were supported by the Swedish International Development Cooperation Agency) and EISA and were deployed at 9074 CENI sites (see RENOSEC 2011; Carter Center 2011a). 
2 December 2011). These missions did an outstanding job, but perhaps had there been a stronger international contingent the Congolese government would have been more fastidious about its electoral organisation.

\section{RESOURCES}

In this section I compare the resources dedicated to the elections in 2011 with those available in 2006. Though many commentators seem to have the impression that a lack of resources was to blame for the problems in 2011 and although it is not clear exactly how much was spent, what is clear is that far more money was spent on these one-round elections with no EU reaction force than on the tworound elections in 2006 when there was a reaction force. It is conceivable that the international community paid almost as much (perhaps more) in 2011 than in 2006. The big difference is that, having funnelled much of the money through the government in general budget support, the international community did not have as much direct control over how it was spent. In addition to its donations the international community played a similar role to that in 2006, though apparently with less intensity.

It is difficult to compare electoral budgets accurately as estimates cover different periods, keep changing, and it is not clear what they include. Donors may have given more or less resources than they promised. A report by the International Crisis Group in May 2011 claimed that the CENI is less financially stable and independent than its predecessor, the Independent Electoral Commission (Commission Électorale Indépendante - CEI) (ICG 2011a). In an article in the Congolese press it was claimed that as of July 2011 the government had given CENI only \$110-million (Congo News Agency 2011). ${ }^{2}$ Despite complaints from the CENI that the international community failed to provide sufficient resources (CENI 2012a) it is possible that international donors contributed about as much to this election as they did to the previous one.

The United Nations Development Programme (UNDP) electoral assistance project (projet d'appui au cycle électoral - PACE) ${ }^{3}$, the European Commission (EC) and IDEA (the International Institute for Democracy and Electoral Assistance) estimated the global cost of the 2005-2006 elections to have been \$517.7-million, including US\$86-million for Monuc logistics (Nanitelamio 2008). The government

2 Unless otherwise specified, all \$ figures represent US dollars.

3 The objectives of Pace are to support the CENI in organising free, transparent and credible national and local elections and to reinforce the CENI's capacity to enable it to manage the electoral cycle properly on a permanent basis. Pace regrouped the funds and efforts of the EU, UK, Belgium, Canada, Netherlands, Sweden, France, Switzerland, Spain, Italy, the Francophonie, Japan, and the UNDP. An EC press release (2 August 2011) stated that in addition to observers the EU provided $€ 47.5 \mathrm{~m}$ for presidential and legislative elections. 
only paid 10\%, approximately US\$52-million (see, eg, Le Potentiel 2010; Congo News Agency 2010) (or US\$32.76-million once the approximately $37 \%$ of foreign funding for the budget is factored out) (IMF 2012).

The cost of the special EU force for the elections (EUFOR RD Congo) was $€ 60$-million (about \$75.6-million in June 2006) (Hoebeke, Carette \& Vlassenroot 2007). Adding EUFOR and subtracting the fully Congolese part of the budget gives an estimate of \$560.54-million of international support in 2006. The CENI claims the global budget for the 2006 elections was US\$550-million, 502-million of which $(91 \%)$ was paid by the international community and 48-million (9\%) by the government (CENI 2012a). It is not clear whether these figures include EUFOR or other international budget assistance. The CENI's March 2012 report mentions several draft combined budgets with one, dated September 2011, containing the figure of \$1 000957527 for 2011-2013 (CENI 2012a). It breaks down this amount into:

- revision of the electoral register: \$94 797844 ;

- organisation of presidential and National Assembly elections: \$264 343559 ;

- operationalisation and reinforcement of capacities: US\$171 910 163;

- logistical assistance from Monusco: US\$74 600 000;

- organisation of provincial elections: US\$169 083 971;

- organisation of local elections: US\$226 221991.

NOTE: the total in fact is $\$ 1000957528$

The CENI report claims that in 2011, 34.05\% of this budget (\$340 557 964) was spent, of which $\$ 257528260$ was used by the government and $\$ 83049074$ by the international partners (Pace and others), with Monusco's logistical support still being evaluated. There are a number of problems with the maths. To begin with, even assuming the total 2011 amount to be correct, it would represent 34.02\%. According to Pace's website, it had spent $\$ 80894605$. This amount does not include funds from donors such as the United States, which gave \$15.5-million, mostly for observation and police training (not to mention US participation in Monusco, debt relief and so on, estimated at \$900-million) (see, eg, US Department of State 2011; US Embassy 2011).

However, these discrepancies are minor compared to others. Just the official amounts budgeted for registration and elections in 2011 add up to \$359 141403 (differing by $\$ 18583439$ from the CENI figure). Furthermore, it would seem logical that the operationalisation and reinforcement of capacities (\$171 910 163) would have to be mostly, if not totally, completed before the elections, not afterwards. 
Without even adding the costs of Monusco's contribution, the same categories of expenses that would have existed in 2006 cost the government \$531 051 566, slightly more than the international election specialists' estimate for the 2006 elections and slightly less than the figure given by the CENI.

Though in September 2011 the government estimated that Monusco's logistical support would cost \$74.6-million (ignoring other forms of assistance), the mission itself had initially budgeted for \$90-million (a figure that apparently took into account, among other costs, the amount required for the use of staff from the Electoral Assistance Division) (UN 2011a). A further \$74 560100 was added on 4 November 2011 for support for the elections for the period from 1 July 2011 to 30 June 2012 to deal with unforeseen costs (UN 2011a). Potential estimates for Monusco's assistance, therefore, range from \$90-million to \$164560 100. Adding these to the $\$ 531051566$ indicates that the costs of the 2011 elections were between $\$ 621051566$ and $\$ 695611666$.

It should be remembered that there was no second presidential round to pay for, though subsequent provincial and municipal elections are included. Rescheduled for 25 February 2013 and 5 February \& 30-31 March 2014, these were subsequently pushed back further pending the reform of the CENI, finally enacted on 27 April 2013 - see below)(CENI 2012b, CENIMonusco UNDP2013a, Monusco2013a).

According to some accounts a lot more money - not less - was spent on the 2011 elections. One journalist claims to have seen a revised budget sent by the CENI to international partners indicating that the cost of the electoral cycle, including local elections in 2013, had risen to \$1.2-billion, with the cost of the November 2011 election alone increased to over \$700-million (much of the government's share allegedly funded by selling state mining assets to China and India) (Hogg 2011).

Given that the government's estimate dates from September 2011 it probably excludes a number of last-minute expenses, so the $\$ 700$-million may be closer to the truth. It is a bit strange that the CENI was not able to come up with a more complete estimate six months after the election; nor was I able to find any other estimate a full year after the elections.

If one accepts the CENI's claim - probably an underestimation - that the international community contributed $\$ 83049704$ to its 2011 budget (without including Monusco's costs) that leaves $\$ 448001862$ for the government to pay. If $42.3 \%$ of the projected DRC Central Government budget comes from international aid, that portion (approximately $\$ 189504788$ ) of the electoral budget should also 
be counted as 'indirect international aid'. ${ }^{4}$ Together with the direct contribution and Monusco's costs, the estimate of international funds spent is between $\$ 362554492$ and $\$ 437114$ 592. If we use the higher figure of $\$ 700$-million then subtract the CENI figure for direct aid, the total is $\$ 616950296$ for the government's portion of the 2011 election budget - 42.3\% of that is \$260969 975. Direct and indirect election aid would be $\$ 344019$ 679. Together with Monusco's costs the figure is between \$434 019679 and \$508 579779 in international assistance.

Although exact figures are not available it is clear that as much or even considerably more money was spent on the 2011 election than on the 2006 election. It is conceivable, if one factors in Monusco's contribution, the part of the DRC budget financed with international aid and non-Pace donors, that the international community paid almost as much (maybe even more) for the one-round/no EUFOR 2011 elections than they did for the two round/EUFOR-secured 2006 elections. The big difference is that, having funnelled much of the money through the government, the international community did not have as much direct control over how it was spent.

Though there has been no clear explanation of the differences, a superficial comparison shows that the international community played a very similar role in both elections, providing technical and logistical assistance, security, 'political services' (including human rights, gender, and so on) and fund management (Nanitelamio 2008). However, according to a diplomatic source there were concrete differences in the degree of participation. Monusco provided about 200 election officials compared to the 600 provided by Monuc. International staff were no longer omnipresent and Monusco had no control over the logistics plan. Whereas the International Committee in Support of the Transition (CIAT) met regularly and was heavily involved in 2006, its successor, the Election Partnership Committee, met very seldom.

Current reports suggest that the CENI continues to have funding problems leading up to provincial elections in 2013 (UN 2012c). The EU, for example, had

4 Hogg (2011) gives a figure of 50\% but does not cite a source. Despite its obvious significance, no one has been able reliably to provide the correct figure. Both the World Bank and the African Development Bank claimed not to have it. The International Monetary Fund (IMF) did not respond; however, there is an estimate in IMF 2011. The projected revenues of and grants to the central government for 2011 total 4 274-billion Congolese francs (about \$4 718282 300), of which 1 268-billion (\$1 399808 600) (approximately 29.7\%) comes from grants and debt relief. The projected expenditure is 5 308-billion francs (\$5 859766600 ). The grants and debt relief only amount to $23.9 \%$ of this figure; however, we get a higher figure if we include Net Foreign Financing, estimated at 979-billion francs (1 158-billion in project loans, 12-billion in debt relief and 192-billion in amortisation due before debt relief. There seems to be 1-million francs more than these figures would indicate, perhaps due to rounding.) If this is included, the total is 2247 -billion francs, divided by the projected expenditure of 5308 -billion francs - amounting to $42.3 \%$ of the budget. 
made its financing dependent on reform of the CENI and an electoral calendar for provincial and local elections (Rolland 2013).

\section{POLITICAL AND SECURITY DEVELOPMENTS}

In some ways, the 2011 election resembled that of 2006, with the same types of electoral violence and allegations of malfeasance. However, there were three big differences. Firstly, instead of the Ugandan-backed warlord Jean-Paul Bemba as his main competition, President Kabila had to face perennial opposition figure Etienne Tshisekedi. Secondly, after initially being seen as the leader of opposition to foreign invasion Kabila came to be regarded by many as having been weak maybe even a bit complicit - in Rwanda's continued destabilisation of the Kivus. Thirdly, this time there was no run-off round for the presidency. In 2006, despite similar problems, the run-off election had allowed Kabila to claim clear legitimacy. Instead, he now has to face lingering questions about whether he would have won another round.

In 2006 two strong, if flawed, candidates faced off and Joseph Kabila clearly beat Jean-Paul Bemba in a reasonably fair vote. Bemba, with his own militia, supported by Uganda, resorted to violence after losing each round. The Congolese Rally for Democracy ('Rassemblement Congolais pour la Démocratie' - RCD-G) showed itself to be the sham, Rwandan-controlled front that everyone except the international community knew it to be.

Long-time opposition figure Etienne Tshisekedi, a minister under the late dictator, Mobutu Sese Seko, went into opposition in 1980 after Mobutu cancelled elections. When Mobutu was forced to open his government to the opposition in the early 1990s Tshisekedi served two separate terms as prime minister in the space of two years. During the transition between the signing of the Global and Inclusive Agreement and the 2006 elections ('the Transition'), he did not feel he was getting the respect he deserved, so he and his party, the Union for Democracy and Social Progress (Union pour la démocratie et le progrès social - UDPS), boycotted the 2006 election, claiming it was rigged in advance.

In 2006 Kabila had some real achievements to his credit. Following the assassination of his father he had supported the transition and the deployment of Monuc. The country was reunited and inflation tamed. Though still in bad shape, the country had made great strides from where it had been when he took over. Compared to his major opponents in the presidential race he looked reasonably good, particularly in the east, which was managed by Rwandan and Ugandan controlled proxies. Since winning a mandate in 2006, however, at the urging of the West and the UN, he allowed (without consulting the National Assembly and the Senate) the brutal army of Rwandan President Paul Kagame to enter 
the DRC once again, displacing a further 900000 Congolese citizens and adding thousands more rapes and deaths to the millions since 1994 (see Hubert 2010; Congo Advocacy Coalition 2009). ${ }^{5}$ This cost Kabila a great deal of support.

Vital Kamerhe, who ran his previous campaign and was president of the National Assembly, defected and formed his own party, Union for the Congolese Nation (Union pour la nation congolaise - UNC). Though there had been some moves to improve governance of natural resources these were counterbalanced by other moves to shore up presidential power and charges of cronyism that had not been addressed. At the start of 2011 Bemba was sitting in the dock of the International Criminal Court in The Hague, not because of the atrocities he had committed in the DRC as Uganda's proxy but because of those his troops had allegedly committed in the Central African Republic in support of former president Ange-Félix Patassé.

His 2006 'boycott strategy' having failed, Tshisekedi mounted a vigorous campaign. Perhaps fearing he might lose a run-off election, Kabila changed the 2006 Constitution by means of Law No 11/ 002 of 20 January, which instituted a one-round presidential election system, waiving the requirement that the winning candidate needs more than $50 \%$ in the first round to avoid a second round and allowing a candidate to win the presidency with less than $50 \%$ of the vote (see ICG 2011).

The pretext - not without merit - was that a poor country like the DRC could ill afford to pay for a second round. However, besides the steep financial cost mentioned above, as many observers anticipated, this proved extremely damaging to the credibility of his win and will probably cost a lot more in the long term. Another suggestion was that an alternate vote ballot should be used (see, eg, UN2011b; Christian Science Monitor 2011; Ulfelder 2011), though this may have proved too much for the already overwhelmed electoral administration.

In addition to the constitutional change, the CEI, run by respected Catholic prelate Apollinaire Malu Malu, was replaced by the CENI, led by Pastor Daniel Ngoy Mulunda, a founding member of Kabila's People's Party for Reconstruction and Democracy (Parti du peuple pour la reconstruction et la démocratie-PPRD). Observers noted important problems in voter registration, candidates' widely varied access to media, and political violence (see, eg, Carter Center 2011a; ICG 2011).

5 For proof of US encouragement, see John F Kennedy Jr Forum 2010. Regarding deaths caused by a previous attempt to eliminate the Democratic Forces for the Liberation of Rwanda by force at the behest of Rwanda see Human Rights Watch 2009. As opposed to those troops sent in 'clandestinely' to support the M23, these troops were apparently still operating as late as September 2012, when Rwanda announced it was officially 'withdrawing' those it had sent in to supposedly hunt down the FDLR with 'official' permission. See, eg, AETA 2012. 
The Audiovisual and Communication High Council (Conseil Supérieur de l'Audiovisuel et de la Communication - CSAC), which replaced the High Media Authority just two months before the elections as the government agency responsible for ensuring equal access to public media during elections, was accused of bias in the administration of its mandate. EU mission chief Mariya Nedelcheva noted that presidential candidates did not get equal access to the national television network, with Kabila receiving $86 \%$ of airtime against just $1 \%$ for Tshisekedi. Nedelcheva also noted the nomination of 18 new magistrates by the president, raising doubts about the independence of the Supreme Court, which was charged with examining the preliminary results and declaring them official (AFP 2011).

A UN human rights report documented 188 violations between 1 November 2010 and 30 September 2011 apparently linked to the electoral process and relating to freedom of expression, physical integrity, liberty and security of individuals and freedom of peaceful assembly (Monusco \& OHCHR 2011). Most of these incidents directly involved elements of the Congolese National Police or the National Intelligence Service targeting supporters of the opposition parties.

International observers also expressed concern about violent pre-election demonstrations. Human Rights Watch (2011) reported at least 18 civilians dead and 100 seriously wounded in electoral violence between 26 and 28 November. The majority of those killed were shot by the Republican Guard in Kinshasa. Other civilians were killed and injured in fighting between rival political parties, attacks by armed groups, and mob violence.

On election day there were incidents of violence related to suspected fraud, augmented by the poor preparation of electoral lists. Many citizens had been left off the lists and their late posting, just before the election, allowed little chance to demand a revision. Electors and officials were often unsure whether a particular voter could vote. Late and insufficient materials at some polling stations did not help either. EU observers noted attempted ballot box stuffing in several provinces, undelivered election materials, unsealed ballot boxes, voters turned away from polling stations and other problems. In some cases, when election officials or others tried to stop apparent fraud, they were threatened or attacked by those committing the fraud, some of them members of the security forces.

Several polling stations were burned down following allegations of ballot box stuffing. In other areas there were attempts to intimidate electors into voting a certain way, notably by Erasto Ntibaturama of the former Rwanda-backed rebel militia-turned political party, the National Congress for the Defense of the People (CNDP). Observers say he compelled voters to vote for his son, Bahati Ibatunganya, and for Kabila. Following the elections there were violent demonstrations, resulting in harsh crackdowns. In a report contested by the 
government, the UN Joint Human Rights Office claimed that defence and security forces had killed at least 33 people and injured 83 others between 26 November and 25 December 2011 as well as arbitrarily arresting 265 civilians (see UNJHRO 2012; Ministère de la justice 2012).

Presidential candidate and head of the Senate, Léon Kengo, had called for a recount, but nonetheless attended Kabila's swearing in. He was subsequently violently attacked in Paris - an attack the government blamed on Tshisekedi supporters (France 24 International News 2012). On the positive side, the violence was much milder than that in 2006, probably because, unlike Bemba, Tshisekedi did not have his own personal, foreign-backed army. Other heavy-handed responses were applied to the media. The CSAC suspended two broadcast networks without an official decision according to the regular process and one newspaper close to the opposition. In Tshisekedi's stronghold of Mbuji Mayi police closed down broadcaster RLTV without legal cause. Even Radio France International was shut down. Following international pressure most media restrictions were lifted (see Stearns 2012).

\section{ELECTION EVALUATION}

There are stark differences among the evaluations of the different monitoring missions. All international observers noted that voting day was generally peaceful and that the Congolese people showed their determination to live in a democracy by walking long distances and suffering long waits to vote (see, eg, AU, SADC, ECCAS, ICGLR \& COMESA 2011; EU 2011; Carter Center 2011b; AETA/EurAc 2011; Monusco 2011). For the missions of the AU, SADC and other African interstate organisations this seemed to be enough and they ratified the results (AU, SADC ECCAS, ICGLR \& COMESA 2011; BBC Africa News 2011).

The Francophonie (which, in addition to numerous African members also had some important Western ones) limited itself to calling for respect for the legal process, for non-violence and for inclusive dialogue (La Francophonie 2012). Most Western and Congolese missions expressed a more critical view.

The Carter Center (2011c) was particularly scathing, saying the quality and integrity of vote tabulation varied across the country and the results 'lacked credibility'; though it also said the serious problems observed did not necessarily mean the final order of candidates would have been any different. It highlighted the loss of 2000 polling station results in Kinshasa and extremely high turnout in pro-Kabila Katanga contrasted with average participation in pro-Tshisekedi Kasai Occidental. The Center also noted delays in announcing results, a lack of proper observer access to the tabulation process and some severe restrictions on media and communication. 
After voting ended, opposition candidates and observers complained that the results had not been properly separated by polling station, as required by law. The EU EOM asked that, in the name of transparency, detailed results be posted at the local compilation centres as well as on the CENI's internet site. This appears to have been done initially only to voting-centre level, but, according to a diplomatic source the results were subsequently distributed on CDs to interested parties (see CENI site; AETA 2011). The conclusions of the Catholic Church's observation mission were broadly similar in tone (CENCO 2012). It denounced the chaos, irregularities and violence and called for an overhaul of the CENI.

The report of the National Electoral Observation Mission (Mission nationale d'observation 2011) included a number of pointed criticisms, including fraud, as did the report of the 'Voice of the Voiceless for Human Rights' (La Voix des Sans-Voix pour les droits de l'homme - VSV 2012). VSV also decried a lack of political culture, saying neither Kabila nor Tshisekedi (who declared himself the winner even before the vote) (UN 2012a), seemed prepared to accept defeat. All the Congolese missions called for calm, for the rule of law to be upheld and for an inclusive national dialogue to sort out the problem, though neither the president nor Tshisekedi seemed interested (Radio Okapi 2012a).

The civil society coalition, AETA, came closest to saying that Tshisekedi had won. In a letter to the UN secretary-general it wrote that the DRC had a 'legal President that was not legitimate and a president who was legitimate but not legal'. It asked either for a recount or a second round of presidential elections organised concurrently with provincial ones. It also requested that Monusco be given the mandate to observe elections and protect Tshisekedi (AETA 2012a \& b). It was a strange request in the light of the fact that Tshisekedi himself blamed Monusco for the electoral problems and derided an international investigation mission (Clottey 2012; Radio Okapi 2011 updated 2012).

Immediately following the vote the opposition candidates, Léon Kengo, Antipas Mbusa and Adam Bombole, demanded the vote be annulled but this did not include Tshisekedi, confident that he would win anyway (AETA 2011b). Many observers worried about his veiled threats of upheaval (see, eg, www. udps.org; AFP 2011). On 9 December the CENI announced that Kabila had won, with 8880944 votes (48.95\%), followed by Tshisekedi with 5864775 votes $(32.33 \%)$ and Kamerhe with 1403372 votes (7.74\%). On 12 December the CENI sent the provisional results to the Supreme Court for validation. Kamerhe at first appeared to call for annulment then accepted the vote while maintaining accusations of large-scale fraud before being the only candidate to petition formally for nullification (see, eg, www.vital-kamerhe.com; Hogg \& Lewis 2011). The application was turned down on 12 December and Kabila was formally declared the winner (UN 2012a, paras 9-10). Kamerhe then asked on his website for Kabila to be impeached (Kamerhe 2012). 
Tshisekedi, too, objected to the official result, instructed the army to stop obeying Kabila (BBC Africa News 2011), had himself sworn in as president and announced he would shortly form a Cabinet (Radio Okapi 2012b), though he has not yet done so. After a period of what some called a form of 'tacit house arrest' Tshisekedi ventured out to meet the German Ambassador on 27 February 2012 (Jeune Afrique 2012; Radio Okapi 2012c, 2012e).

Several opposition groups banded together to form a 'National Resistance Council', whose goal was to get to 'the truth of the ballot boxes' (Le Phare 2012). A delegation led by Kamerhe went to an AU meeting in Addis Ababa to lobby African heads of state, even though many had been elected in circumstances far dodgier than those of Kabila (Congo News 2012). They tried to participate in a pacific 'Christian march' organised on 16 February 2012 by the Catholic Church. After the governor of Kinshasa banned the march police forced demonstrators to stay inside their churches and used tear gas against some (AETA 2012a, 2012b; Colombant 2012).

The presidential camp responded to allegations of fraud by saying that, although there had been irregularities they were not sufficiently severe to have given Tshisekedi a higher number of votes than Kabila (AETA 2011a). In support of this claim, they published a number of simulations, purporting to show that, even if all the votes from 'questionable' districts were given to Tshisekedi he would have 1641013 fewer than Kabila and maintained that all candidates had received high levels of support where expected. The explanation for the extremely high levels of votes for the president in certain areas was that proxy votes had been used and that it had been decided to allow voters who had their cards but whose names had been left off the electoral lists to vote.

Following all the drama of the elections draft amendments to the Organic Law on the Organization and Functioning of the Independent National Electoral Commission were submitted to the National Assembly on 24 September 2012 (UN 2012c). The majority and the opposition disagreed on elements such as the composition of the CENI's executive board and the establishment of a plenary body. On 7 October 2012 a special commission, with members from both sides, was established in an effort to reach a compromise and Law 13/012 of 13 April 2013 was signed into effect by President Kabila on 27 April 2013. The new commission comprised: 13 members, six from the majority, four from the opposition and three from civil society.

\section{LEGISLATIVE ELECTIONS}

With all the drama over the presidential results legislative elections were somewhat ignored, though, in some ways, they were more contentious. The same 
number of missing or fraudulent ballots in a given district, while not significant enough to change the presidential standings, can make a difference in a local race.

After several postponements most of the provisional results were published on 1 February 2012 (CENI 2012a), although the CENI later claimed to have published them on 26 January. The CENI sought to annul elections in seven districts affected by violence and demanded legal action against 20 candidates accused of participating in violence (CENI 2012a). The districts were: Kiri in the east of Bandundu, Ikela in Equateur, Masisi in North Kivu, Kole and Lomela in Kasai Oriental, Punia in Maniema and Demba in Kasai Occidental.

According to Article 73 of Law no 11 / 003 of 25 June 2011 candidates and their parties had eight days within which to contest the results. The Supreme Court received 507 important legislative challenges (Carter Center 2012) and had two months within which to examine the complaints (Art 74 Law 11/003). On 27 April 2012 the court invalidated the election of 32 members of the National Assembly owing to irregularities and fraud, instated 31 other candidates in their place (validated by the Assembly on 4 May) and ordered a by-election for the Befale constituency in Equateur (UN 2012b). In the same ruling, the court approved the CENI's petition to nullify the results in Masisi because of significant irregularities, but ordered it to publish the results from the other six districts. This was done on 8 September 2012 (UN 2012c).

On 4 August 2012 the CENI maintained it would not be possible to hold byelections in Masisi due to insecurity, so, on 18 September, the court directed the commission to overturn its decision to cancel the results there and on 2 October the CENI published provisional results for that district. Following an appeal by the attorney general the Supreme Court ordered the Assembly to decide on the validity of the mandates of the seven deputies from Masisi and on 12 December 2012 they were confirmed (see, eg, Radio Okapi, 2012g).

General results of the elections for the Assembly roughly followed the tendencies of those in the presidential ballot. The main presidential party, the PPRD remained in first place, but the number of representatives dropped from 111 to 62 (CENI 2012a). However, the president could still count on significant support from other parties (see, eg, AETA 2012c).

Many Congolese politicians, like those in other countries, are adept at following their own interests. The 'presidential majority' in the National Assembly is around two-thirds, though it may be difficult to manage its components. Some candidates from competing pro-presidential parties contested each other's elections in court. ${ }^{6}$ It is also notable that the number of seats won by Bemba's MLC was much diminished (from 64 to 22), whereas Tshisekedi's UDPS, after

6 For a list of court appeals so far, see Tshiambi 2012. See also RFI 11 Feb 2012. 
boycotting the 2006 election, was now the leading opposition party - and the second-strongest party after PPRD, with 41 seats. However, having sworn himself in as president, Tshisekedi 'annulled' the legislative elections and the UDPS boycotted the Assembly. ${ }^{7}$ Tshisekedi expelled from his party the 33 UDPS deputies who insisted on taking their seats (UDPA 2012a, 2012b). Given that most of the members took up their seats and that the Assembly does not need the UDPS to function, it is questionable whether the party is more effective shouting from outside rather than being inside.

\section{INTERNATIONAL REACTION: NEGATIVE SOFT POWER}

After the presidential results were published Monusco and the international community called for calm, verification of results, national dialogue and the pursuit of grievances though the courts (see, eg, Monusco 2011a; Radio Okapi 2012d). The United States suggested a technical review (US Department of State 2011a, 2011b), but a joint mission by the International Foundation for Electoral Systems (IFES) and the National Democratic Institute (NDI) was frustrated in its attempts to bring clarity. Its only conclusion was to recommend a broad review of the electoral process with all stakeholders and access to electoral materials (NDI-IFES 2012).

Activists complained about the fact that the US was not more forthright in condemning the results and more proactive in pressuring the government (Colombant 2011) but, judged by the standards of American diplomacy and regional democracy, the American response was quite harsh, with critics saying that the elections had not measured up to 'democratic gains' in other African countries and criticising the pace of reform in general (see US Department of State 2011a, 2011 b; Baer 2012).

The activists were, however, forced to admit that the obvious flaws did not necessarily mean that the order of candidates would have been different from that announced by the CENI. Having failed to convince the government not to abolish the second round, they could not confidently say that Kabila had not won the election under the new rules. It is worth repeating that although the Election Partnership Committee was supposed to be equivalent to the CIAT it was considered almost moribund. Also, as stated above, although the international community did, in fact, provide massive funding for the 2011 election, this was mostly done indirectly through general budget support, giving it considerably less leverage.

The hectoring of the international community would be more effective if the community were more coherent in its treatment of sub-Saharan governments. 
'Soft Power' is the ability to influence through example, attraction and legitimacy (Nye 2004). 'Negative soft power' repels when behaviour is not seen as legitimate, especially when it contradicts lofty rhetoric.

The current Rwandan and Ugandan regimes are responsible for the deaths of close to seven million people in the region. Using development aid and Western military assistance these regimes have organised and controlled the chaos, rape and pillage in the DRC. President Paul Kagame of Rwanda has outlawed, beaten, murdered and imprisoned his opposition (see, eg, Reid 2009, pp 133-196; Hirondelle News Agency 2005; BBC News 2004 and 2008, EU 2003, Immigration \& Refugee Board of Canada 2006, Economist 2010, Amnesty 2010, Human Rights Watch 2010). Despite these crimes, Kagame was named co-chair of the UN's Millennium Development Goals Advocacy Group (UN 2010; UN Department of Public Information 2010; Iacobini de Fazio 2010; Russell Lee 2010; Lynch 2010) and awarded a Global Citizen Award for 'Leadership in Public Service' by former US President Bill Clinton (Clinton Global Initiative 2009). Despite the fact that under his leadership there was massive recruitment of child soldiers and scores of children died, the US Fund for Unicef honoured Kagame with its Children's Champion Award (see Unicef).

Despite the fact that he had caused countless rapes through his wars and destabilisation of the Great Lakes region (see, eg, Reid 2011; Baaz \& Stern 2010), Liberian president and Nobel Peace Prize winner Ellen Johnson-Sirleaf awarded Kagame Liberia's highest honour for 'services to women' (Rwanda New Times 2009).

As it pushed for the rule of law in the DRC, the US State Department filed a Suggestion of Immunity on 29 August 2011 on behalf of Kagame for acts committed before he became head of state (Habyarimana et al v Kagame 2011). Kagame was represented by former US Ambassador for War Crimes, Pierre-Richard Prosper (Arent Fox 2011; Al Jazeera 2011). Despite the well-documented pillage by Rwanda and Uganda of the DRC, the international community has not pressured Rwanda or Uganda to join the Extractive Industries Transparency Initiative (EITI). ${ }^{8}$

Over the objections of the DRC and Human Rights Watch, Rwanda was voted onto the UN Security Council on 18 October 2012 (UN News Centre 2012), the day after a leaked UN report again confirmed the Rwanda government's control of the brutal 'rebel' group, M23 (Security Council 2012b, 2012a; BBC News 2012a \& b; Wallis 2012; Smith 2012). Even the UK Foreign \& Commonwealth Office,

8 The initiative was launched by Former British Prime Minister Tony Blair at the World Summit on Sustainable Development in Johannesburg in September 2002. It supposedly 'aims to ensure that the revenues from extractive industries contribute to sustainable development and poverty reduction'. Despite their well-known pillage of the DRC and the fact that the UK is a major bilateral donor to Rwanda and Uganda, it has been unable or unwilling to get them to sign on. This is perhaps not surprising given the influence of Blair and that former UK Secretary of State for International Development, Clare Short, notorious for her unquestioning heavy support of these two rogue states, has been chair of the board since 2011 . 
normally Rwanda's staunchest supporter, expressed its confidence in the Panel of Experts Report (UK Foreign \& Commonwealth Office 2012).

Within a week of this demonstration of international impunity for the Rwandan Patriotic Front, its proxy, M23, went on the offensive again and took Goma, the capital of North Kivu, on 20 November, with little apparent action or reaction from Monusco or the international community (Radio Okapi 2012f; Plett, B 2012; BBC 2012c; Briggs 2012). As in 2006 when another Rwandan-backed Congolese Tutsi warlord took Bukavu, mobs attacked UN installations and government buildings (see Monusco 2012).

According to Refugees International, as of November 2012 more than 2.4million Congolese had been internally displaced and more than 460000 had become refugees in neighbouring countries (Refugees International 2012). Susan Rice, the US Ambassador to the UN, who has frequently defended the RPF regime and who has tried to block the publication of UN reports critical of Rwanda, was President Obama's lead candidate to replace Hillary Clinton as Secretary of State before her candidacy was derailed by unrelated events in Libya (see, eg, Stearns 2012; Congo Siasa 2012; Hirsh 2012; Rosenblum 2002, pp 195-202). Seeing others rewarded for bad governance, why would the Kabila administration feel obliged to act differently?

In contrast to the West's 'convenient' morality, China does not pretend to care about elections, but it does bring real assets to bear. Canada is the natural resource capital of the world and Canadian listed companies are amongst the most important involved in the DRC, yet Canada refused, in 2010, to send one of its generals to lead the peacekeeping force. In contrast, China has had medical and engineering contingents in its mission for almost a decade. In 2008 China's Export-Import Bank promised to lend \$9-billion to build and upgrade $3200 \mathrm{~km}$ of rail and $4000 \mathrm{~km}$ of road and develop and rehabilitate the mining sector in exchange for copper and cobalt concessions (eStandards Forum 2009). They will also construct two hydro-electric dams, rehabilitate water supply facilities, build 31 hospitals, 150 health centres, 4 large universities, a new parliament and 20000 residences. Congolese will form $80 \%$ of the work force.

The IMF was against further debt relief to the DRC because of the size of the loan, state guarantees and the barter nature of the project, so the agreement was reduced to \$6-billion (eStandards Forum 2009; Economist Intelligence Unit March 2010, p 18). A similar deal, worth \$750-million, was made with Korean corporations to provide water infrastructure, also in exchange for Katangan mines (eStandards Forum 2009, p 11; Economist Intelligence Unit March 2010, p 10). The point is that emerging powers see the strategic importance of Africa that the West has missed and are engaging in partnerships rather than in 'charity'. This makes African governments less dependent on Western aid and less susceptible to criticism over lapses in democratic practice. 


\section{CONCLUSION}

According to the principle of 'national ownership' the Congolese government should have played a much more important role in 2011 than it did in 2006, but, as in fragile post-conflict countries everywhere, this role resulted in a more partisan and less competent electoral administration. Had the international community been as hands-on as it was in 2006 some might have accused it of 'neo-colonialism'. Nonetheless, that is not an excuse for not maintaining better statistics and ensuring that aid achieves its intended goals.

Given its support for the Congolese budget, the international community still paid for a large portion of the costs, though without commensurate oversight. The technical flaws observed in 2006 were aggravated in 2011, without the second round of presidential elections which would have bolstered legitimacy. Though there was large-scale fraud it is not clear that, in fact, any other candidate would have won, given the rules in place ... The main problem was not insufficient voter education or too few international monitors (Congolese civil society did a sterling job) but rather a history of international complacency and complicity with war criminals and bad governance which makes pious statements about democracy seem insincere. The fact that China and other rising powers are starting to exploit the strategic potential that Western powers have ignored further diminishes leverage for democracy and human rights.

It was unlikely that the government or the international community would pay for another election. The interesting idea of combining the national and provincial elections did not go anywhere. The most likely scenario is that a Kabila administration with diminished legitimacy will limp along until the next national elections. There will be sporadic acts of violence against and from the government. It would be difficult to stage a full rebellion without the sort of outside interference that the Congolese have, rightly, come to mistrust.

Tshisekedi's relatively advanced age (almost 80 ) could both spur him on to obtain change quickly and tire him out. Vital Kamerhe may take over the role of chief figurehead of the opposition. His principled stand against Rwandan troops and his role in the transition might make him acceptable both to the Congolese and to the international community. The best hope for the future is sustained action by Congolese civil society but the West can help by combining a demand for rule of law with a Chinese-style partnership for development. 


\section{REFERENCES}

Agir pour les Elections Transparentes et Apaisées (AETA). 2011a. 'Documents préparés par des experts de la Majorité Présidentielle pour réfuter l'analyse du Centre Carter sur la crédibilité des résultats partiels proclamés par la CENI le 9 décembre 2011'. Available at: www.aeta-network.org/ documents-prepares-par-des-experts-de-la-majorite-presidentielle-pourrefuter-1\%E2\% $80 \% 99$ analyse-du-centre-carter-sur-la-credibilite-des-resultats-partiels-proclames-par-la-ceni-le-9-decembre-2011?lang=en

AETA. 2011b. ‘RDC: les candidats Kengo, Mbusa et Bombole demandent un nouveau scrutin présidentiel', 15 December. Available at: www.aeta-network. org/rdc-les-candidats-kengo-mbusa-et-bombole-demandent-un-nouveauscrutin-presidentiel

AETA. 2012a. 'Déclaration sur la crise post-électorale en RD Congo', 28 January. Available at: www.aeta-network.org/organisations-de-la-societe-civilecongolaiseaeta-declaration-sur-la-crise-post-electorale-en-rd-congo

AETA. 2012b. ‘Future Assemblée nationale/ PPRD, PPPD, MSR ... UDPS: les principaux groupes parlementaires', 1 February. Available at: www.aetanetwork.org/future-assemblee-nationale-pprd-pppd-msr\%E2\%80\%A6udpsles-principaux-groupes-parlementaires

AETA. 2012c. 'Lettre de la Société Civile Congolaise au S.G des Nations Unies sur la Crise Post-Electorale en RDC', 7 February. Available at: www.aeta-network. org

AETA. 2012d. 'Kinshasa: le gouverneur interdit la marche des chrétiens', 16 February. Available at: www.aeta-network.org/kinshasa-le-gouverneur-interdit-lamarche-des-chretiens

AETA. 2012e. 'Rwandais au Kivu Kabila en difficulté', 5 September. Available at: www.aeta-network.org/rwandais-au-kivu-kabila-en-difficulte

AETA / Réseau Européen pour l'Afrique Centrale (EurAc). 2011. 'Journée du scrutin en RDC: premières observations', 30 November. Available at: www.aetanetwork.org/aetaeurac-journee-du-scrutin-en-rdc-premieres-observations

Agence France Presse (AFP). 2011a. 'EU finds DR Congo vote irregularities', 1 December. Available at: news.yahoo.com/conspiracy-theories-swirl-drcongo-awaits-vote-results-144700598.html

AFP. 2011b. 'DR Congo opposition leader issues warning over vote tally', 4 December. Available at: www.capitalfm.co.ke/news/2011/12/dr-congoopposition-leader-issues-warning-over-vote-tally/

Al Jazeera. 2011. ‘US court dismisses lawsuit against Kagame-Oklahoma court says Rwandan president has immunity as head of state in lawsuit over deaths of two African presidents', 29 October. Available at: www.aljazeera.com/news / americas / 2011/10/20111029145039353562.html

Amnesty International. 2010. 'Rwanda: End human rights clampdown before presidential elections'. Public Statement 24 April: AI Index: AFR 47/003/2010. Available at: www.amnesty.org/en/library/info/AFR47/003/2010/en 
Arent Fox. 2011. 'Arent Fox Wins Dismissal of Wrongful Death Suit Filed Against President of Rwanda'. Press Release, 1 November. Available at: www.arentfox. $\mathrm{com} /$ newsroom/index.cfm?fa=pressReleaseDisp\&content_id=3396

$A U, S A D C$, Economic Community OfThe Central African States (ECCAS), International Conference On The Great Lakes Region (ICGLR) \& Common Market For Eastern And Southern Africa (COMESA). 2011. 'Joint Declaration on the Presidential and Parliamentary Elections in the Democratic Republic OfCongo'. Available at: www. au.int/en/sites/default/files/Joint_Statement_-_English\%5B1\%5D.pdf

Baaz, M E \& M Stern. 2010. 'The Complexity of Violence: A critical analysis of sexual violence in the Democratic Republic of Congo (DRC)'. Swedish International Development Cooperation Agency (SIDA) - The Nordic Africa Institute. Available at: www.sida.se

Bafilemba, F. 2011. 'Congo's Kabila revises Constitution: presidential candidates now only need a plurality'. The Christian Science Monitor - CSMonitor.com: Africa Monitor, 19 January. Available at: www.csmonitor.com/World/ Africa / Africa-Monitor / 2011 / 0119/Congo-s-Kabila-revises-Constitutionpresidential-candidates-now-only-need-a-plurality

BBC Africa News. 2004. 'From president to prison', 7 January. Available at: news. bbc.co.uk/2/hi/africa/3728807.stm

BBC Africa News. 2008. ‘Timeline: Rwanda - A chronology of key events', 20 March. Available at: news.bbc.co.uk/2/hi/africa/1070329.stm

BBC Africa News. 2011a. 'DR Congo election hailed a success by African observers', 30 November. Available at: www.bbc.co.uk/news/world-africa-15959155

BBC Africa News. 2011b. 'DR Congo's Tshisekedi orders army to disobey Kabila', 19 December. Available at: www.bbc.co.uk/news/world-africa-16243472

BBC Africa News. 2012a. 'DR Congo's M23 rebels threaten to march to Kinshasa', 12 November. Available at: www.bbc.co.uk/news/world-africa-20427682

BBC Africa News. 2012b. 'Rwanda defence chief leads DR Congo rebels UN report says', 17 October. Available at: www.bbc.co.uk/ news / world-africa-19973366

BBC Africa News. 2012cb. 'Rwanda voted onto UN Security Council', 18 October. Available at: www.bbc.co.uk/news/world-19998195

Briggs, C. 2012. 'Fall of Goma Shows Monusco's Failings'. Refugees International, 20 November. Available at: refugeesinternational.org/blog/fall-goma-showsmonuscos-failings

Carter Center, The. 2006a. 'Preliminary Statement on the October 29 Presidential Elections in the Democratic Republic of the Congo', 1 November. Available at: www.cartercenter.org/news/pr/drc_runoff_preliminary.html

Carter Center, The. 2006b. 'Second Carter Center Post-Election Statement on the October 29 Presidential Elections in the Democratic Republic of the Congo', 15 November. Available at: www.cartercenter.org/news/pr/DRC_111506.html Carter Center, The. 2006c. 'Third Carter Center Post-Election Statement on the October 29 Presidential Elections in the Democratic Republic of the Congo', 27 November. Available at: www.cartercenter.org/news/pr/third_DRC.html 
Carter Center, The. 2011a. 'First Carter Center Pre-Election Statement on Preparations in the Democratic Republic of Congo', 17 October. Available at: www.cartercenter.org/news/publications/election_reports.html\#drc

Carter Center, The. 2011b. 'Preliminary Post Election Statement'. The Carter Center International Election Observation Mission - Democratic Republic of Congo, Presidential and Legislative Elections, 28 November. Available at: www. cartercenter.org/news/publications/election_reports.html\#drc

Carter Center, The. 2011c. 'DRC Presidential Election Results Lack Credibility', 10 December. Available at: www.cartercenter.org/news/pr/drc-121011.html

Carter Center, The. 2012. 'Carter Center: Democratic Republic of the Congo Legislative Election Results Compromised', 23 February. Available at: www. cartercenter.org/news / pr / drc-022312.html

CENI. 2012a. 'Les Élections Présidentielles et Législatives du 28 Novembre 2011 en République Démocratique du Congo: Défis, Stratégies et Résultats'. Kinshasa: Commission Électorale Nationale Indépendante (CENI) de la République Démocratique du Congo, March. Available at: www.aeta-network.org/ rapport-d $\%$ E2\% 80\%99evaluation-de-la-commission-electorale-nationaleindependante-ceni

CENI. 2012b. Élection des députés Nationaux de 2011 - Résultats provisoires, 26 January. Available at: docs.google.com/viewer?a=v\&pid=explorer\&chrome =true\&srcid=0B3GJKd5i8PncYmZlNzY5ZmItZGRmMi00YzdmLTllODgtM TJjM2I2ZmQ1N2U3\&hl=en_GB\&pli=1

CENI. 2012c. Décision No 019/CENI/BUR/12. Press Statement, 10 November. Available at: www.aeta-network.org/ceni-le-calendrier-pour-les-electionsprovinciales-deja-connu

CENI, Monusco, UNDP. 2013a. 'Note d'information - Processus électoral Actualité du processus électoral : Situation au 16 janvier 2013'. Available at: monusco. unmissions.org/LinkClick.aspx?fileticket=CuW8-x6451I\%3d\&tabid=11253 $\& \mathrm{mid}=14404 \&$ language $=$ fr-FR

Christian Science Monitor. 2011. 'Congo's Kabila revises Constitution: presidential candidates now only need a plurality', 19 January. Available at: www. csmonitor.com/World / Africa / Africa-milliononitor / 2011 / 0119/ Congos-Kabila-revises-Constitution-presidential-candidates-now-only-need-aplurality

Clinton Global Initiative. 2009. ‘Former President Clinton Announces Winners of the Third Annual Clinton Global Citizen Awards'. Press Release, 23 September. Available at: press.clintonglobalinitiative.org/press_releases/ former-president-clinton-announces-winners-of-the-third-annual-clintonglobal-citizen-awards/

Clottey, P. 2012. 'DRC Opposition Figure Blames Monusco for Election Debacle'. VOANews, 1 January. Available at:www.voanews.com/english/news/africa/ DRC-Opposition-Figure-Blames-Monusco-for-Election-Debacle-136501173. html 
Colombant, N. 2011. 'Activists, Analysts Express Frustration at US Congo Policy'. VOA News 27 December. Available at: www.voanews.com/ english/news/africa/ Activists-Analysts-Express-Frustration-at-US-CongoPolicy-136283298.html

Colombant, N. 2012. 'While March in Kinshasa is Banned, Analysts Fear for Congo'. VOA News 16 February. Available at: www.voanews.com/english/ news / africa / While-March-in-Kinshasa-is-Banned-Analysts-Fear-forCongo-139483743.html

Conférence Episcopale Nationale du Congo (CENCO). 2012. 'Message de la CENCO aux fideles et au peuple congolais: "le courage de la vérité"', 12 January. Available at: www.cheikfitanews.net/ article-document-millionessage-de-lacenco-aux-fideles-et-au-peuple-congolais-le-courage-de-la-verite-96973775. html

Congo Advocacy Coalition. 2009. 'Congo Advocacy Coalition letter to United Nations: Civilian Protection Now', 6 February. Available at: www. enoughproject.org

Congo News Agency. 2010. 'Parliament to Tackle Elections 2011 Budget during September Session', 14 September. Available at: www.congoplanet.com/ news / 1738/ parliament-to-tackle-elections-2011-budget-during-septembersession.jsp

Congo News Agency. 2011. '31 Million Registered to Vote', 20 July. Available at: www.congoplanet.com/news/1861/dr-congo-presidential-election-thirtyone-million-registered-to-vote.jsp

Congo News. 2012. 'Kamerhe, Félix, Fayulu: mission accomplie à Addis-Abeba', 1 February. Available at: www.7sur7.cd / index.php?option=com_ content\&view=article\&id=29595:-kamerhe-felix-fayulu--mission-accompliea-addis-abeba\&Itemid $=2$

Congo Siasa, 24 Nov 2012. Available at: congosiasa.blogspot.com/

Economist, The. 2010. 'A Rwandan shooting - Who is out to kill the dissidents? As an election looms, the politics of Rwanda become a lot nastier', 24 June. Available at: www.economist.com/node/16439016? story_ id $=16439016 \& f s r c=n l w \mid$ wwp $\mid$ 06-24-2010 | politics_this_week

Economist Intelligence Unit. 2010. 'Country Report: Democratic Republic of Congo', March. Available at: store.eiu.com/

EITI. Available at: www.eitransparency.org/

eStandards Forum. 2009. Country Brief-Democratic Republic OfThe Congo. eStandards Forum Financial Standards Foundation, November 12. Available at: www. estandardsforum.org

EurAc \& AETA. 2011. 'RDC, Élections du 28 novembre 2011: Mission d'observation électorale', 2 December. Available at: www.radiovaticana.org/FR1/articolo. asp?c $=542946$

European Commission (EC). 2011. 'Democratic Republic of the Congo: EU observers for presidential and parliamentary elections'. Press release, 2 August. 
Available at: europa.eu/rapid / pressReleasesAction.do?reference $=\mathrm{IP} / 11 / 9$ $45 \&$ format $=$ HTML\&aged $=0$ \&language $=E N \&$ guiLanguage $=$ en

European Union (EU). 2003. Mission d'Observation Électorale de l'UE Rwanda 2003. 'Rapport final sur l'élection présidentielle et les élections législatives'. Available at: ec.europa.eu/external_relations/human_rights/eu_election_ ass_observ/rwanda/moe_ue_final_2003.pdf

EU. 2011. Mission d'observation électorale de l'Union européenne en République démocratique du Congo 2011. ‘Une forte mobilisation de l'électorat dans un processus insuffisamment maîtrisé'. Press release, Kinshasa, 1 December. Available at: www.moeue-rdc.eu

EU. 2012. Available at: www.eueom.eu / ue-moe-rd-congo-2011/ home

Financial Standards Foundation. 2009. 'Country Brief - Democratic Republic Of The Congo', 12 November. Available at: www.estandardsforum.org

France 24 International News. 2012. 'Head of DR Congo Senate attacked in Paris', 2 January. Available at: www.france24.com/en/20120101-democraticrepublic-congo-senate-chief-attacked-paris-leon-kengo

Hirondelle News Agency (Lausanne). 2005. 'Former Rwandan President Bizimungu Back in Court', 20 April.

Hirsh, M. 2012. 'Susan Rice: Benghazi May Be Least of Her Problems'. National Journal, 16 November. Available at: news.yahoo.com/susan-rice-benghazimay-least-her-problems-060007367--politics.html

Hoebeke, H, S Carette \& K Vlassenroot. 2007. 'EU support to the Democratic Republic of Congo'. Centre d'analyse stratégique. Available at: www. egmontinstitute.be/papers / 07/afr/EU_support_to_the_DRC.pdf

Hogg, J. 2011. 'Congo election may be delayed on logistics setback, costs'. Reuters, 31 August. Available at: af.reuters.com/article/drcNews/ idAFL5E7JV2Y220110831

Hogg, J \& D Lewis. 2011. 'Congo's Kamerhe withdraws call to annul elections'. Reuters, 1 December. Available at: news.yahoo.com/congos-kamerhewithdraws-call-annul-elections-053548439.html

Refugees International. 2012. Available at: refugeesinternational.org/where-wework/africa/dr-congo

www.unicefusa.org/news/releases/unicef-and-the-boston-celtics.html www.flickr.com/photos/paulkagame/3886156291/

Hubert, T. 2010. 'Doubts over UN, government military shift in Congo'. Relief Web: Briefing Kit for Reuters - AlertNet + Rwanda. Reuters, 14 January, compiled on 10 July 2011. Available at: reliefweb.int/node/340371

Human Rights Watch. 2009. 'You Will Be Punished - Attacks on Civilians in Eastern Congo', 13 December. Available at: www.hrw.org/node/ 871510

Human Rights Watch. 2010. 'Rwanda: Protect Rights and Safety of Opposition Leaders', 15 October. Available at: www.hrw.org/en/news/2010/10/15/ rwanda-protect-rights-and-safety-opposition-leaders

Human Rights Watch. 2011. ‘DR Congo: Rein in Security Forces: Tensions Mount 
Ahead of Election Results', 2 December. Available at: www.hrw.org/ news / 2011/12/02/dr-congo-rein-security-forces

Iacobini de Fazio, M. 2010. 'U.N. Chief Returns from “Damage Control” Trip to Rwanda'. Inter Press Service News Agency, 9 September. Available at: ipsnews.net $/$ africa $/$ nota.asp?idnews $=52778$

International Crisis Group (ICG). 2011a. 'Congo: The Electoral Dilemma'. Africa Report 175, 5 May.

ICG. 2011b. 'Congo: The Electoral Process Seen from the East'. Update Briefing, Africa Briefing 80, 5 September. Available at: www.crisisgroup.org

IFES. 2012. 'NDI-IFES Election Experts Recommend Broad Review of Electoral Process in the Democratic Republic of Congo', 25 January. Available at: www. ifes.org/Content / Publications / Press-Release / 2012 / NDI-IFES-ElectionExperts-Recommend-Broad-Review-of-Electoral-Process-in-the-DRC.aspx or www.aeta-network.org/wp-content/ uploads / 2012/01 / ATT484631.pdf

IMF. 2011. 'Democratic Republic of the Congo: Third Review of the Three-Year Arrangement Under the Extended Credit Facility, Financing Assurances Review, and Request for Modification of Performance Criteria - Staff Report and Press Release on the Executive Board Discussion'. IMF Country Report 11(190), July.

IMF. 2012. 'Democratic Republic of the Congo: Selected Issues and Statistical Appendix'. IMF Country Report 7(329), September. Available at: www.imf. org/ external/pubs / cat/longres.aspx?sk=21353.0

Immigration and Refugee Board of Canada. 5 May 2006. 'Rwanda: Treatment by government authorities of Faustin Twagiramungu and supporters of his candidacy during the presidential election campaign in August 2003 (August 2003-April 2006)'. Reference \#: RWA101284.FE. Available at http:/ / www. irb-cisr.gc.ca:8080/RIR_RDI/RIR_RDI.aspx?l=e\&id=451418

John F. Kennedy Jr Forum, Harvard University. 2010. 'Engaging Africa as a Strategic Partner: Diplomacy, Development, and Defense', 6 April. Available at: forum. iop.harvard.edu/ content/ engaging-africa-strategic-partner-diplomacydevelopment-and-defense

Kamerhe, V. 2012. 'Actions en destitution de Joseph Kabila ...'. Available at: www. vital-kamerhe.com/action-en-destitution-de-Joseph-Kabila.html

Kamerhe, V website. www.vital-kamerhe.com

La Voix des Sans-Voix pour les droits de l'homme. 2012. 'Rapport final sur l'observation des élections présidentielle et législatives du 28 novembre 2011 en République Démocratique du Congo', January. Available at : www. vsv-rdc.com/

Le Phare. 2012. 'Vérité des urnes en RDC: Le Conseil National de la Résistance sur pied de guerre-Joseph Olenghankoy élu Coordonnateur', 1 February. Available at: www.7sur7.cd /index.php?option=com_content\&view=article\&id=29598:verite-des-urnes-en-rdc--le-conseil-national-de-la-resistance-sur-pied-deguerre-joseph-olenghankoy-elu-coordonnateur\&Itemid=2 
Le Potentiel. 2010. 'La CEI annonce un budget de 712 millions USD pour le processus electoral', 14 August. Available at: www.congoplanete.com/article. jsp?id $=45262863$

Lynch, C. 2010. 'Did Ban Ki-moon's advisors try to spare Rwanda from genocide charge?' Foreign Policy, 3 September. Available at: turtlebay.foreignpolicy. com/posts / 2010/09/03/did_ban_ki_moon_s_advisors_try_to_spare_ rwanda_from_genocide_charge

Mémorandum additionnel sur l'armée et la sécurité. Signed on 6 March 2003 in Pretoria.

Ministère de la justice et droits humains de la République Démocratique du Congo. 2012. 'Réaction du Gouvernement au Rapport d'enquête du Bureau conjoint des Nations Unies aux droits de l'homme (HCDH-Monuc) sur les allegations des violations graves des droits del'homme imputées aux members des forces de sécurité et de défense congolaises dans la ville de Kinshasa, en RDC, entre le 26 novembre et le 25 décembre 2011', 14 March. Available at: www.ohchr. org/EN/countries / AfricaRegion/Pages /ZRIndex.aspx

Mission d'observation électorale de l'Union européenne en République démocratique du Congo 2011. 2011. 'Une forte mobilisation de l'électorat dans un processus insuffisamment maîtrisé'. Press Release, Kinshasa 1 December. Available at: www.moeue-rdc.eu

Mission Nationale d'observation. 2011. 'Rapport de la Mission Nationale d'observation: Observation de la compilation des elections legislatives du 28 novembre 2011', 19 January. Available at: fr-fr.facebook.com/notes/ union-pour-la-nation-congolaise-unc-en-sigle-page-officielle/ rapport-dela-mission-nationale-dobservation / 274021059326985

Monusco. 2011a. 'Presidential and National Legislative Elections: Roger Meece appeals for calm', 1 December. Available at: monusco.unmissions.org/ Default.aspx?tabid $=4640 \& c t l=$ Details\&mid $=5262 \&$ ItemID $=15841$

Monusco. 2011b. 'Monusco calls on INEC to address electoral observer missions concerns'. Press Release, 12 December. Available at : monusco.unmissions. org / Default.aspx?tabid $=4640 \& c t l=$ Details\&mid $=5262 \&$ ItemID $=15947$

Monusco. 2012. 'UN Under Attack'. Available at: monusco.unmissions.org/Default. aspx?tabid $=10662 \&$ language $=$ en-US

Monusco. 2013a. 'Nr 5 Bulletin Electoral - 01 au 15 Janvier 2013'. Available at http: / / monusco.unmissions.org/LinkClick.aspx?fileticket=G6CSGalZVYU\%3d\&t abid $=11253 \&$ mid $=14677 \&$ language $=$ fr-FR

Monusco \& OHCHR. 2011. 'Report of the United Nations Joint Human Rights Office on Human Rights And Fundamental Freedoms During the Pre-Electoral Period in the Democratic Republic of Congo', November. Available at http:/ / www.ohchr.org/Documents/Countries/ZR/UNJHRO_HRElectionsReport_ en.pdf

Nanitelamio, S-P. 2008. 'APEC \& PACE projects and the collaboration between the EC, the UNDP and IDEA in the DRC'. In Joint Training on Effective 
Electoral Assistance, Maputo, 23-27 June. Available at: www.google.ca/ url? sa $=$ t\&rct $=$ j\&q $=\% 20$ apec $\% 20 \% 26 \% 20$ pace $\% 20$ projects $\% 20$ and $\% 20$ the $\% 20$ collaboration $\% 20$ between $\% 20$ the $\% 20$ ec $\% 2$ C $\% 20$ the $\% 20$ undp $\% 20$ and $\% 20 \mathrm{idea} \% 20 \mathrm{in} \% 20$ the $\% 20 \mathrm{drc} \&$ source $=$ web\&cd $=1 \&$ ved $=0 \mathrm{CCYQFjA}$ A\&url $=$ http $\% 3 \mathrm{~A} \% 2 \mathrm{~F} \% 2 \mathrm{Fwww}$.ec-undp-electoralassistance.org $\% 2$ Findex. php\%3Foption\%3Dcom_docman\%26task\%3Ddoc_download\%26gid\%3D7 0\%26Itemid\%3D\&ei=bbwMT4KuBqrw0gGl89SSBg\&usg=AFQjCNFTsFrk0 x2uMLLqmDu627LqGAsQXg

Nye, J S Jr. 2004. Soft Power: The Means to Success in World Power. Cambridge, MA: BBS Publications.

Organisation Internationale de la Francophonie. 2011. 'Le Secrétaire général de la Francophonie dépêche une mission d'information et de contact en République Démocratique du Congo'. Press Statement CP/SG/33/JT/11, 22 November. Available at: www.francophonie.org/Le-Secretaire-general-de-la,38464.html Organisation Internationale de la Francophonie. 2012. ‘Le Secrétaire général de la Francophonie appelle à l'apaisement et au respect des principes démocratiques dans la poursuite du processus électoral en RDC'. Press Statement CP/ SG/02/JT/12. Paris, 20 January. Available at: www.francophonie.org/LeSecretaire-general-de-la,39058.html

PACE (UNDP). Available at: www.cd.undp.org/projet.aspx?titre=Projet $\% 20$ d $\% 27$ Appui\%20au $\%$ 20Cycle $\% 20$ Electoral $\% 20 \% 28$ PACE $\% 29 \&$ projetid $=1$

Plett, B. 2012. 'UN under fire over fall of Goma in DR Congo'. BBC, 21 November. Available at: www.bbc.co.uk/news / world-africa-20422340

Radio France Internationale (RFI). 2012a. 'En RDC, la Cour suprême de justice sous le «flot» des recours des candidats aux legislatives', 11 February. Available at: www.rfi.fr / afrique / 20120211-rdc-cour-supreme-justice-recours-candidatslegislatives-Evariste\%20Boshab-

RFI. 2012b. 'RDC : violente intervention policière contre des fidèles regroupés dans des églises', 16 February. Available at : www.rfi.fr/afrique/20120216-rdcviolente-intervention-policiere-contre-fideles-regroupes-eglises

Radio Okapi. 2011 (updated 2012). 'Etienne Tshisekedi : «Les experts internationaux de la Ceni viennent en touristes "', 31 December, 3 January. Available at : radiookapi.net/actualite/2011/12/31/etienne-tshisekedi-les-expertsinternationaux-viennent-en-touriste/

Radio Okapi. 2012a. 'RDC: 1'opposition et la majorité réagissent au dialogue KabilaTshisekedi proposé par la VSV', 10 January. Available at: radiookapi.net/ actualite/2012/01/10/rdc-lopposition-la-majorite-reagissent-au-dialoguekabila-tshisekedi-propose-par-la-vsv /

Radio Okapi. 2012b. ‘Tshisekedi affirme être officiellement entré en fonction comme chef de l'Etat', 20 January. Available at: www.congoplanete.com/news/3416/ etienne-tshisekedi-va-former-son-gouvernement.jsp

Radio Okapi. 2012c. 'Le Renadhoc condamne «l'assignation tacite en résidence surveillée» d'Etienne Tshisekedi', 1 February. Available at: www.aeta-network. 
org / le-renadhoc-condamne- $\% \mathrm{C} 2 \% \mathrm{ABl} \% \mathrm{E} 2 \% 80 \% 99$ assignation-tacite-enresidence-surveillee $\% \mathrm{C} 2 \% \mathrm{BB}-\mathrm{d} \% \mathrm{E} 2 \% 80 \%$ 99etienne-tshisekedi

Radio Okapi. 2012d. 'Législatives-RDC : la Monusco encourage le recours aux voies légales', 3 February. Available at : radiookapi.net/actualite/2012/02/03/ legislatives-rdc-la-monusco-encourage-le-recours-aux-voies-legales /

Radio Okapi. 2012e. 'Tshisekedi Leaves "House Arrest" to Meet German Ambassador', 27 February. Available at: www.congoplanet.com/news/1948/ etienne-tshisekedi-leaves-house-arrest-to-meet-german-ambassador.jsp

Radio Okapi. 2012f. 'Goma: retour sur les événements majeurs de la semaine', 23 November. Available at: radiookapi.net/ actualite/2012/11/23/goma-retoursur-les-evenements-majeurs-de-la-semaine/

Radio Okapi, 2012g. 'RDC: l'Assemblée nationale valide les mandats de 7 députés de Masisi', 14 December. Available at: http:/ / radiookapi.net/ actualite / 2012/12/14/ rdc-lassemblee-nationale-valide-les-mandats-de-7deputes-de-masisi/

Reid, T. 2009. 'War is not Politics by Other Means: A Case Study of how Western Indulgence Encouraged Rwanda and Uganda to Undermine the Security and Sovereignty of the Democratic Republic of Congo'. In M Franco (ed). A UE E ÁFRICA: EM BUSCA E PACERIA DE PARCERIA ESTRATÉGICA (The EU and Africa: Looking for Strategic Partnership). Lisbon: Fundaçào Luso-Americana \& Instituto Portugués de Relações Internacionais.

Reid, T. 2011. 'Rapes in the Congo: More Than a Weapon of War'. The InterDependent, a publication of the United Nations Association of the United States of America. Available at: www.theinterdependent.com/110729/rapes-in-thecongo-more-than-a-weapon-of-war

RENOSEC. 2011. 'Le rapport à mi-parcours de l'Observation des élections du 28 novembre 2011'. Available at: www.lephareonline.net/lephare/index. php?option=com_content\&view=article\&id=4765:renosec--le-rapport-a-miparcours-de-lobservation-des-elections-du-28-novembre-2011\&catid=54:rok stories\&Itemid $=107$

Résolutions Adaptées. Accord global et inclusif sur la transition en République Démocratique du Congo. Signed on 17 December 2002 in Pretoria.

'RDC, Élections du 28 novembre 2011: Mission d'observation électorale'. Réseau Européen pour l' Afrique Centrale (EurAc) and AETA ('Agir pour les Elections Transparentes et Apaisées': Action for Transparent and Calm Elections): 02 Dec 11. Available at: www.radiovaticana.org/FR1/articolo.asp?c=542946

RFI. 2012. 'En RDC, la Cour suprême de justice sous le «flot» des recours des candidats aux legislatives'. RFI, 11 February. Available at: www.rfi.fr/ afrique / 20120211-rdc-cour-supreme-justice-recours-candidats-legislativesEvariste\%20Boshab-

Rolland, P R. 2013. 'Financement du processus électoral en RDC. L'UE conditionne son appui à la mise en place de la CENI et de la CNDH'. L'Avenir Quotidien via AETA, 15 March. Available at: www.aeta-network.org/financement-du- 
processus-electoral-en-rdc-lue-conditionne-son-appui-a-la-mise-en-placede-la-ceni-et-de-la-cndh

Rosenblum, P. 2002. 'Irrational Exuberance: The Clinton Administration in Africa'. Current History 101.

Russell Lee, M. 2010. 'As UN's Ban's Choice of Kagame Triggers Spanish Boycott, Role of UNDP's Clark; Rwandan to Get UN Women Post?' Inner City Press, 16 July. Available at: www.innercitypress.com/mdg1kagame071610.html Rwanda New Times. 2009. 'Rwanda: Liberia Awards Kagame with Highest Honour (Distinction of the Grand Cordon in the Most Venerable Order of the Knighthood of Pioneers)', 8 March. Available at: allafrica.com/ stories / 200903091268.html

Security Council. 2012a. 'Letter dated 21 June 2012 from the Chair of the Security Council Committee established pursuant to resolution 1533 (2004) concerning the Democratic Republic of the Congo addressed to the President of the Security Council': S / 2012/348 and its its addendum: S/2012/348/Add.

Security Council. 2012b. 'Letter dated 12 November 2012 from the Chair of the Security Council Committee established pursuant to resolution 1533 (2004) concerning the Democratic Republic of the Congo addressed to the President of the Security Council'. S/2012/843.

Smith, D. 2012. 'Rwandan minister is leader of Congo rebels UN says'. The Guardian 18 October. Available at: www.guardian.co.uk/world/2012/ oct/17/rwandaminister-leader-congo-rebels-kabarebe

Southern African Development Community (SADC). 2011. 'SADC Launches Electoral Observer Mission in DRC'. Media Release 12 November. Available at: www.sadc.int/english/current-affairs/news/

Stearns, J. 2012. 'Susan Rice and the M23 crisis'. Congo Siasa, 24 November 2012. Available at: congosiasa.blogspot.com/

Stearns, S. 2012. 'US Calls on Congo to Restore RFI Broadcasts'. VOA News, 5 January. Available at: www.voanews.com/english/news / africa/US-Calls-on-Congoto-Restore-RFI-Broadcasts0-136767223.html

Swiss Info. 2011. 'Swiss act as election observers in Congo' 24 November. Available at: www.swissinfo.ch/eng/politics/Swiss_act_as_election_observers_in_ Congo.html?cid $=31629986$

Times of Zambia, The. 2011. '25-Member COMESA Team to Observe Local Polls', 24 November. Available at: allafrica.com/stories/201111240330.html

Tshiambi, A. 2012. 'Contentieux électoraux: les recours s'amoncellent déjà à la Cour suprême'. Le Potentiel 1 February. Available at : www.aeta-network. org/contentieux-electoraux-les-recours-s\%E2\%80\%99amoncellent-deja-ala-cour-supreme

Tshisekedi, E. Available at: www.udps.org/index.php?option=com_content\&vie $\mathrm{w}=$ article $\& \mathrm{id}=447 \&$ catid $=40 \&$ Itemid $=90$

Tshitenge Lubabu, M K. 2012. 'RDC: chez Étienne Tshisekedi, dans l'antre du Sphinx'. Jeune Afrique 26 January. Available at : www.jeuneafrique.com/ 
Article/JA2662p032-033.xml0 / president-rfi-jacob-zuma-kinshasardc-cheztienne-tshisekedi-dans-l-antre-du-sphinx.html

UK Foreign and Commonwealth Office. 2012. 'UN Group of Experts report on the Democratic Republic of Congo', 22 November. Available at: www.fco.gov. uk/en/news / latest-news / ?view $=$ News\&id $=837780882$

Ulfelder, J. 2011. 'Can Really Poor Countries Hold Fair and Inclusive Elections?', 2September. Available at: dartthrowingchimp.wordpress.com/2011 /09/02/ can-really-poor-countries-hold-fair-and-inclusive-elections /

Union for Democracy and Social Progress (UDPS). 2012a. 'Déclaration politique de la Présidence du Parti portant constat d'auto exclusion des membres de l'UDPS déclarés élus députés nationaux par la CENI et siégeant'. Nouvelles du Parti, 11 April. Available at: udps.org/docs/declaration_politique_du_10avril2012. pdf

UDPS. 2012b. 'Félicitations aux huit vaillants députés de l'UDPS qui ont résisté à la tentation de bénéficier d'émoluments illégaux et illégitimes', 16 April. Available at: www.udps.org/index.php?option=com_content\&view $=$ article\&id $=477$ :fe licitations-aux-huit-vaillants-deputes-de-ludps-qui-ont-resiste-a-la-tentationde-beneficier-demoluments-illegaux-et-illegitimes\&catid=39:nouvelles-duparti\&Itemid $=89$

Unicef: www.unicefusa.org/news / releases / unicef-and-the-boston-celtics.html; www.flickr.com/photos / paulkagame/3886156291/)

United Nations (UN). 2006. 'Twenty-second report of the Secretary-General on the United Nations Organization Mission in the Democratic Republic of the Congo', S/2006/759.

UN. 2007. 'Twenty-third report of the Secretary-General on the United Nations Organization Mission in the Democratic Republic of the Congo', S/ 2007/156.

UN. 2010. 'Secretary-General's opening remarks at press conference to launch the 2010 Millennium Development Goals report'. Latest Statements, SecretaryGeneral Office of the Spokesperson, New York, 23 June. Available at: www. un.org/apps/sg/sgstats.asp?nid=4629

UN. 2011a. 'Report of the Secretary-General on the United Nations Organization Stabilization Mission in the Democratic Republic of the Congo', S / 2011 / 298, 12 May.

UN. 2011b. 'Financing arrangements for the United Nations Organization Stabilization Mission in the Democratic Republic of the Congo for the period from 1 July 2011 to 30 June 2012. Report of the Advisory Committee on Administrative and Budgetary Questions', A/66/545, 4 November.

UN. 2011c. 'Financial performance report on the budget of the United Nations Organization Mission in the Democratic Republic of the Congo for the period from 1 July 2009 to 30 June 2010 and proposed budget for the United Nations Organization Stabilization Mission in the Democratic Republic of the Congo for the period from 1 July 2011 to 30 June 2012. Report of the Advisory Committee on Administrative and Budgetary Questions', A /65/743 / ADD.8. 
UN. 2012a. 'Report of the Secretary-General on the United Nations Organization Stabilization Mission in the Democratic Republic of the Congo', S/2012/65, 26 January.

UN. 2012b. 'Report of the Secretary-General on the United Nations Organization Stabilization Mission in the Democratic Republic of the Congo', S / 2012/35, 23 May.

UN. 2012c. 'Report of the Secretary-General on the United Nations Organization Stabilization Mission in the Democratic Republic of the Congo', S / 2012 / 838. Distr, 14 November.

UN Department of Public Information. 2010. 'The MDG Advocacy Group List of Members', 25 June. Available at: http://www.un-ngls.org/spip. php?page $=$ amdg10\&id_article $=2685$

UN Joint Human Rights Office (UNJHRO). 2012. ‘Report of the United Nations Joint Human Rights Office on Serious Human Rights Violations Committed by Members of the Congolese Defense and Security Forces in Kinshasa in the Democratic Republic of the Congo Between 26 November and 25 December 2011 '. AND the reply from the government of the DRC: Ministère de la justice et droits humains de la République Démocratique du Congo. 'Réaction du Gouvernement, au Rapport d'enquête du Bureau conjoint des Nations Unies aux droits de l'homme ( $\mathrm{HCDH}$ - Monuc) sur les allegations des violations graves des droits de l'homme imputées aux membres des forces de sécurité et de défense congolaises dans la ville de Kinshasa, en RDC, entre le 26 novembre et le 25 décembre 2011', 14 March 2011. Both available at: www. ohchr.org/EN/countries / AfricaRegion/Pages / ZRIndex.aspx

UN News Centre. 2012. 'Argentina, Australia, Luxembourg, Republic of Korea and Rwanda obtain non-permanent seats on UN Security Council', 18 October. Available at: www.un.org/apps/news/ story.asp?NewsID $=43320 \& C r=S e c u$ rity+Council\&Cr1=\#.ULlUZIVv07B

US Department of State. 2011. 'State's Carson on Improving Governance in the DRC'. Testimony by Assistant Secretary Johnnie Carson, Bureau of African AffairsU.S. Department of State, Before the Senate Foreign Relations Subcommittee on African Affairs: Improving Governance in the Democratic Republic of the Congo'. Text \& Transcript, 15 December. Available at: iipdigital. usembassy.gov/st/english/texttrans/2011/12/20111217154235su0.1032526. html\#axzz1lUiw6qey

US Department of State. 2012. 'State's Baer on U.S. Policy Toward Post-Election DRC': Testimony by Daniel Baer, Deputy Assistant Secretary, Bureau of Democracy, Human Rights, and Labor Testimony Before the House Subcommittee on Africa, Global Health and Human Rights, 2 February. Available at: iipdigital. usembassy.gov/st/english/texttrans/2012/02/20120203112443su0.6734059. html\#axzz1lTj3rgxR

US Department of State - Office of the Spokesperson. 2011a. 'Presidential Elections in the Democratic Republic of the Congo - Statement by Victoria Nuland, 
Spokesperson', 9 December. Available at: iipdigital.usembassy.gov/st/ english / texttrans / 2011/12/20111210142200su0.3268048.html\#axzz1lTj3rgxR US Department of State - Office of the Spokesperson. 2011b. 'Clinton on Supreme Court Ruling on Presidential Election in DRC', 20 December. Available at: iipdigital.usembassy.gov/st/english/texttrans/2011/12/20111220153437su 1.044869e-03.html\#axzz1lTj3rgxR

US Embassy Kinshasa. 2011. 'USA donates $\$ 500,000$ of protective equipment to the Police Nationale Congolaise'. Press Release, 15 November Available at: kinshasa.usembassy.gov/pressrelease_english_11152011.html

Wallis, W. 2012. 'UN panel says Rwanda arming Congo rebels'. Financial Times, 17 October. Available at: www.ft.com / intl/ cms / s / / 8905a350-1836-11e2-80e900144feabdc0.html\#axzz2C35s9OR2

\section{Legislation}

Constitution de la Transition.

Art 73 Loi no 11/ 003 du 25 juin 2011 modifiant la Loi no 06/006 du 09 mars 2006 portant organisation des élections présidentielle, législatives, provinciales, urbaines, municipales et locales.

Loi organique modifiant et complétant la loi n 10/013 du 28 juillet 2010 portant organisation et fonctionnement de la Commission Electorale Nationale Indépendante acc 03 May 2012 at www.digitalcongo.net/UserFiles/file/ PDF_files/2013/loi_ceni.pdf

\section{Conference}

Dialogue Inter-Congolais, Sun City, 25 February to 19 April 2002.

\section{Court case}

Madame Habyarimana, et al., Plaintiffs, v. Paul Kagame, President of the Republic of Rwanda, et al. Civil Action No 10-437-W, United States District Court For The Western District Of Oklahoma Case 5:10-cv-00437-W Document 49 Filed $08 / 29 / 11$ 